\title{
INTERWENCJONIZM A WOLNY RYNEK W ROLNICTWIE KRAJÓW EUROPY ŚRODKOWO-WSCHODNIEJ PRZED I PO PRZYSTĄPIENIU DO UNII EUROPEJSKIEJ
}

\begin{abstract}
Streszczenie
W pracy przedstawiono jedną z metod oceny stopnia interwencjonizmu w obszarze rolnictwa. Badanie przeprowadzono dla rolnictwa: Czech, Słowacji, Litwy, Lotwy, Estonii, Polski i Węgier w latach 1997-2013. Punktem wyjścia przeprowadzonych badań była estymacja dwuczynnikowej funkcji CES, a następnie sprawdzenie wiarygodności spełnienia założeń tej estymacji. W wyniku przeprowadzonych badań dowiedziono, że interwencjonizm w rolnictwie prowadzi w większym stopniu do zaburzeń na rynku kapitału trwałego niż siły roboczej.
\end{abstract}

Słowa kluczowe: konkurencja doskonała, funkcja CES, hipoteza Hicksa, relatywne ceny czynników produkcji, krańcowa stopa substytucji

\section{INTERVENTIONISM AND FREE MARKET IN AGRICULTURE OF CENTRAL AND EASTERN EUROPEAN STATES BEFORE AND AFTER ACCESSION TO EU}

\section{Summary}

The paper presents one of the methods of assessing the degree of intervention in agriculture. The study was conducted for the agricultural sectors of the Czech Republic, Slovakia, Lithuania, Latvia, Estonia, Poland, and Hungary in the period 1997-2013. The starting point of the study was to estimate the two-factor CES production function. Then the validity of the assumptions of the estimation was verified. The analysis shows that interventionism in agriculture affects the market of fixed capital to a greater extent than the labour market.

Key words: perfect competition, CES production function, Hicksian hypothesis, relative prices of production factors, marginal rate of substitution

DOI: $10.15290 /$ ose.2015.01.73.10

\section{Wstęp}

Interwencjonizm państwowy, rozumiany jako aktywne oddziaływanie państwa na sferę gospodarcza, jest cechą niemal wszystkich krajów obecnego świata [np.: Ducz-

${ }^{1}$ Dr Lucyna Błażejczyk-Majka - Zakład Historii Gospodarczej, Wydział Historyczny, Uniwersytet im. Adama Mickiewicza w Poznaniu; e-mail: majkal@amu.edu.pl. 
kowska-Małysz, 1998, s. 127-131]. Wspólna Polityka Rolna (WPR) prowadzona w ramach Unii Europejskiej (UE) również wywierała i wywiera silny wpływ zarówno na procesy produkcyjne, jak i rynkowe [Walkowski, 1998, s. 103]. Od początku jej funkcjonowania rolnictwo unijne wielokrotnie reformowano, co między innymi miało prowadzić do zwiększenia jego konkurencyjności na rynkach światowych [m.in.: Poczta, 2001, s. 5-6; Czyżewski, Henisz-Matuszczak, 2004, s. 115]. Co więcej, działania podejmowane w ramach unijnej polityki rolnej mają z założenia chronić społeczeństwo przed niepożądanymi efektami funkcjonowania rolnictwa na zasadach wolnorynkowych, takimi jak: zanieczyszczenie środowiska, stosowanie w produkcji niedozwolonych substancji bądź technologii czy też nieetyczne zachowania w stosunku do zwierząt i konsumentów. Z drugiej strony polityka dopłat pośrednich i bezpośrednich [np.: Poczta, 2010, s. 41-42] jest bardzo kosztowana i może zakłócać działanie mechanizmów wolnorynkowych [np.: Duczkowska-Małysz, 1998, s. 127-131].

Zwiększenie możliwości wytwórczych tak w sensie ilościowym, jak i jakościowym jest możliwe do osiagnięcia dzięki wprowadzaniu postępu w procesie produkcji. Proces ten może przyjąć formę nowych: wyrobów, technologii, umiejętności, rozwiązań instytucjonalnych i organizacyjnych [Woś, 1987, s. 186]. Ponadto można go łączyć z jednym z czynników wytwórczych: postęp związany z siłą roboczą lub postęp techniczny związany z kapitałem.

W warunkach konkurencji doskonałej, zgodnie z hipotezą Hicksa [Hicks, 1932, s. 124-125], bodźcem do innowacji i wynalazków w procesie rozwoju są zmiany w relatywnych cenach czynników produkcji, które wywołują substytucję czynników produkcji uzasadnioną rachunkiem ekonomicznym. Przy czym Allen [Allen, 1961, s. 662] wykazał, że wartość efektu zastapienia jednego czynnika produkcji innym nie może być mniejsza niż koszt związany z tą zmianą. W dłuższej perspektywie, dzięki wprowadzanym innowacjom, możliwe jest ciąłe przekraczanie osiagniętych wcześniej wartości granicznych substytucji [Woś, 1998, s. 41-43]. Źródłem innowacji mogą być więc czynniki rynkowe, dotyczące zmian w relatywnych cenach czynników wytwórczych. Mamy wtedy do czynienia z postępem typu endogenicznego.

Z drugiej strony uznaje się także, że interwencjonizm unijny w obszarze rolnictwa napędza wydajność i innowacje w rolnictwie krajów członkowskich [Zrozumiećpolityke Unii Europejskiej - Rolnictwo, 2013, s. 11]. Fakt ten zatem potwierdza, że źródłami postępu moga być również czynniki pozarynkowe: egzogeniczne. W ten sposób w obszarze pracy można tu przytoczyć politykę rent strukturalnych dla rolników wymuszających wcześniejszą wymianę pokoleniową. Z kolei jako przykład postępu egzogenicznego związanego z kapitałem można traktować działania wspierające rozwój w tym obszarze, np.: kredyty preferencyjne na modernizację procesu produkcji obejmującą bezpieczeństwo fitosanitarne.

Wilkin [Wilkin, 1986, s. 52-70] wyraził opinię, że praktyki protekcjonistyczne w Unii Europejskiej powodują niewłaściwą alokację produkcji i kształtowanie nieprawidłowej struktury cen zarówno artykułów rolnych, jak i przemysłowych. Jego zdaniem, protekcjonizm ten powoduje, że postęp techniczny w krajach unijnych może być źle ukierunkowany. Natomiast inne spojrzenie na znaczenie polityki rolnej przedstawił Woś [Woś, 1998, s. 11-12]. Podkreśla on, że rolnictwo generuje zbyt słabe siły wewnętrzne, 
które mogłyby wywołać proces wzrostowy i utrzymać go w stanie dynamicznej równowagi. Bez odpowiedniej ingerencji ze strony państwa efekty postępu technicznego w rolnictwie mogą być więc zbyt małe, a taka sytuacja jest jednym z powodów ustalenia się równowagi rynkowej poniżej optimum w całej gospodarce.

Celem pacy jest zatem próba wskazania metod ilościowych, które pozwoliłyby udzielić odpowiedzi na pytania: na ile wprowadzany do produkcji rolniczej postęp, związany z działaniem w ramach UE WPR, zakłóca procesy rynkowe i czy prawdziwe są założenia WPR, że interwencjonizm w obszarze rolnictwa unijnego wpływa na poprawę jego konkurencyjności.

Punktem wyjścia do odpowiedzi na te pytania jest estymacja dwuczynnikowej funkcji CES (Constant Elasticity of Substitution) przy założeniu, że produkcja odbywa się w warunkach konkurencji doskonałej. Weryfikacja przyjętych założeń może służyć ocenie, na ile działania protekcjonistyczne, podejmowane w ramach WPR, zakłócały warunki konkurencji na rynku produktów żywnościowych. Co więcej, działanie to pozwala na wskazanie obszarów i okresów, w których kierunek postępu, związanego bądź z siłą roboczą bądź z szeroko rozumianym kapitałem, nie miał uzasadnienia rynkowego. Natomiast nie poruszono w pracy przyczyn i konsekwencji występujących różnic. Zagadnienia te będa przedmiotem dalszych badań autora.

Odpowiednie badania zostały przeprowadzone w odniesieniu do rolnictwa wybranych krajów Europy Środkowo-Wschodniej, które w 2004 roku uzyskały pełne członkostwo w Unii Europejskiej: Polski, Węgier, Czech, Słowacji. Litwy, Lotwy i Estonii w latach 1997-2013. Wybór okresu badawczego wynikał z dostępności danych, ale był wystarczający, aby porównać odpowiedzi na postawione pytania w okresie przedakcesyjnym i po uzyskaniu pełnego członkostwa w UE. Analizy zostały przeprowadzone na podstawie danych publikowanych w ramach agendy EUROSTAT [EUROSTAT, 2014]. W badaniu uwzględniono, obok wielkości produkcji i cen produktów rolnych, dwa podstawowe czynniki produkcji: pracę i kapitał oraz ich ceny.

\section{Metodyka}

Zależności pomiędzy wykorzystywanymi w procesie produkcji czynnikami a uzyskanymi efektami są w teorii ekonomii opisywane za pomoca funkcji produkcji. Jedna z nich jest funkcja CES (Constant Elasticity of Substitution). Funkcja ta w ujęciu dynamicznym przyjmuje następująca postać [Arrow i in., 1961; Welfe, Welfe, 2004, s. 57]:

$$
Q_{i}=A\left[v\left(L_{i} E_{L}\right)^{-\rho}+(1-v)\left(K_{i} E_{K}\right)^{-\rho}\right]^{-\frac{1}{\rho}} i=1,2, \ldots, n,
$$

gdzie $Q_{i}$ oznacza wielkość produkcji w danym okresie, a $L_{i}$ i $K_{i}$ to odpowiednio wielkości zaangażowanej $\mathrm{w}$ proces produkcji pracy i kapitału. $E_{L}=E_{L}(t)$ oraz $E_{K}=E_{K}(t)$ są funkcjami określającymi efekty postępu technicznego, ukierunkowanego odpowiednio na pracę i kapitał.

Przyjęty we wzorze (1) zapis oznacza, że postęp techniczny wpływa w różny sposób na czynniki zaangażowane w proces produkcji [Felbur, 1993, s. 6; Marciniak, 2000, s. 23; Pawłowski, 1976, s. 98-99]. Pozostałe wielkości stanowia parametry funkcji 
CES. Tym samym parametr $v(0>v>1)$ oznacza udział siły roboczej i kapitału w ogólnej wielkości produkcji. Z kolei parametr $A(A>0)$ to wydajność stosowanej techniki, nazywany także w literaturze parametrem efektywności [np.: Klump, Preissler, 2000]. Parametr $\varrho(\varrho>-1)$ jest określany zwykle jako parametr substytucyjny i jest ściśle związany z elastycznością substytucji [np.: Intriligator i in., 2000, s. 286]:

$$
\sigma=\frac{1}{1+\rho}
$$

W warunkach konkurencji doskonałej, zgodnie z hipotezą Hicksa [Hicks, 1932, s. 124-125], produktywności krańcowe obu nakładów są równe ich cenom realnym [np.: Allen, 1961, s. 347; Begg i in., 1995, s. 555]. Stwierdzenie to w odniesieniu do funkcji CES można zapisać w postaci:

$$
w_{i}=p_{i} A^{-\rho} v\left(\frac{Q_{i}}{L_{i}}\right)^{1+\rho} E_{L}, r_{i}=p_{i} A^{-\rho}(1-v)\left(\frac{Q_{i}}{K_{i}}\right)^{1+\rho} E_{K},
$$

gdzie $w_{i}$ jest ceną pracy, $r_{i}$ ceną kapitału, a $p_{i}$ cena produktu. Stąd w szczególności wynika zależność:

$$
\frac{w_{i}}{r_{i}}=\frac{v}{1-v}\left(\frac{K_{i}}{L_{i}}\right)^{1+\rho_{1}} \frac{E_{L}}{E_{K}},
$$

odwrócony stosunek cen czynników produkcji jest równy ich krańcowej stopie substytucji. W tej sytuacji elastyczność substytucji $\sigma$ zapisaną we wzorze (2) uznaje się za tożsamą z elastycznością substytucji Hicksa [np.: Chiang ,1994, s. 425]:

$$
\sigma=\frac{d \ln \left(L_{i} / K_{i}\right)}{d \ln \left(r_{i} / w_{i}\right)}
$$

Wartość $\sigma$ mówi, o ile procent zmniejszy się relatywne zużycie jednego czynnika produkcji, jeżeli relatywna cena drugiego czynnika produkcji wzrośnie o 1\% [np.: BłażejczykMajka, Kala, 2005].

W podejściu tym jest również konieczne zdefiniowanie uwzględnionych we wzorze (1) funkcji postępu technicznego $E_{L}$ oraz $E_{K}$. Spośród wielu możliwości [np.: Żółtowska, 1997, s. 40-43; Solow, 1962; Kawagoe i in., 1986] przyjęto funkcje postaci:

$$
E_{L}=\exp \left(-\delta t^{\gamma}\right) \ldots . E_{K}=\exp \left(-\lambda t^{\gamma}\right) t=1,2, \ldots, \mathrm{n} .
$$

Jeżeli $\delta>\lambda$, to oznacza, że postęp techniczny silniej oddziałuje na siłę roboczą niż na kapitał, co w efekcie powoduje silniejsze ograniczenie zużycia siły roboczej w procesie produkcji. Takie rozwiązanie dopuszcza zmienne stopy przyrostu nakładów w wyniku działania postępu technicznego oraz chroni model przed nadmierną rozbudowa. Zostało ono zaprezentowane w monografii Błażejczyk-Majki i Kali [Błażejczyk-Majka, Kala, 2009, s. 17-18]. Dobór wykładnika $\gamma$ zostanie przeprowadzony droga optymalizacyjna, przy której dopasowanie modeli jest najwyższe.

Porównanie w czasie przebiegu ilorazu cen czynników produkcji oraz zmian krańcowej stopy substytucji pomiędzy tymi czynnikami, przedstawionych we wzorze (4), pozwoli odpowiedzieć na pytanie, czy dana produkcja odbywała się bez naruszenia reguł 
wolnorynkowych. Z kolei bardziej szczegółowa analiza, przeprowadzona na podstawie równości (3), umożliwia wskazanie obszarów, w których w badanym okresie wystąpiły ewentualne zakłócenia.

\section{Estymacja funkcji CES}

Punktem wyjścia do oszacowania przedstawionej we wzorze (4) krańcowej stopy substytucji jest estymacja parametrów funkcji CES. Ze względu na nieliniowość tej funkcji bezpośrednia ocena jej parametrów, przeprowadzona na podstawie szeregów czasowych, natrafia na trudności. Rozwiązanie tego problemu może opierać się na wykorzystaniu metod iteracyjnych, których przegląd można znaleźć między innymi w monografii Żółtowskiej [Żółtowska, 1997, s. 81-183]. Natomiast zastosowanie metod regresji jest możliwe przy wykorzystaniu założeń zaprezentowanych we wzorze (3). Stąd zlogarytmowanie zależności opisanej w równaniu (4) prowadzi do modelu:

$$
\boldsymbol{Y}=\boldsymbol{X} \boldsymbol{\beta}+\boldsymbol{\varepsilon},
$$

gdzie $\boldsymbol{\varepsilon}$ jest wektorem błędów losowych, który stosując rozwiązanie zaproponowane przez Yeung i Roe [Yeung, Roe, 1971, s. 5-10] polegające na zastosowaniu do estymacji metody Zellnera [Zellner, 1962], przyjmuje postać:

$$
Y=\left[\begin{array}{c}
\ln \left(\frac{Q_{1}}{L_{1}}\right) \\
\cdots \\
\ln \left(\frac{Q_{n}}{L_{n}}\right) \\
\ln \left(\frac{Q_{1}}{K_{1}}\right) \\
\ldots \\
\ln \left(\frac{Q_{n}}{K_{n}}\right)
\end{array}\right], X=\left[\begin{array}{ccccc}
1 & 0 & \ln \left(\frac{w_{1}}{p_{1}}\right) & t_{1}^{\gamma} & 0 \\
\ldots & \ldots & \ldots & \ldots & \ldots \\
1 & 0 & \ln \left(\frac{w_{n}}{p_{n}}\right) & t_{n}^{\gamma} & 0 \\
1 & 1 & \ln \left(\frac{r_{1}}{p_{1}}\right) & 0 & t_{1}^{\gamma} \\
\cdots & \ldots & \ldots \\
1 & 1 & \ln \left(\frac{r_{n}}{p_{n}}\right) & 0 & t_{n}^{\gamma}
\end{array}\right], \beta=\left[\begin{array}{c}
\beta_{1} \\
\beta_{2} \\
\sigma \\
\beta_{\delta} \\
\beta_{\lambda}
\end{array}\right]=\left[\begin{array}{c}
\beta_{1} \\
\beta_{2} \\
\frac{1}{1+\rho} \\
\frac{\delta \rho}{1+\rho} \\
\frac{\lambda \rho}{1+\rho}
\end{array}\right],(7)
$$

gdzie $\beta_{1}=\frac{-\ln \left(A^{-\rho} v\right)}{1+\rho}$, a $\beta_{2}=\frac{1}{1+\rho} \ln \left(\frac{v}{1-v}\right)$.

Oszacowane w ten sposób współczynniki regresji $\beta$ dają podstawę do wyznaczenia parametrów $\delta, \lambda, \varrho$ :

$$
\begin{array}{r}
\rho=\frac{1-\sigma}{\sigma}, \delta=\frac{\beta_{\delta}}{1-\sigma}, \lambda=\frac{\beta_{\lambda}}{1-\sigma}, \\
v=\frac{\exp \left(\beta_{2}(1+\rho)\right)}{1+\exp \left(\beta_{2}(1+\rho)\right)}, A=\left(\frac{\exp \left(-\beta_{1}(1+\rho)\right)}{v}\right)^{-\frac{1}{\rho}},
\end{array}
$$


które z kolei umożliwią wyznaczenie krańcowej stopy substytucji dla każdego roku badanego okresu (porównaj wzór (4)).

\section{Materiał badawczy}

Badania zostały przeprowadzone dla rolnictwa następujących państw Europy Środkowo-Wschodniej: Słowacji, Czech, Litwy, Lotwy, Estonii, Polski, Węgier. W analizie wykorzystano dane statystyczne udostępniane w ramach agendy EUROSTAT [EUROSTAT, 2014] i dotyczące rolnictwa w latach 1997-2013.

TABELA 1.

Indeksy wartości zmiennych w 2013 roku $(1997=100)$

\begin{tabular}{|l|c|c|c|c|c|c|}
\hline & $\begin{array}{c}\text { Produkcja } \\
\text { rolnicza }\end{array}$ & $\begin{array}{c}\text { Siła ro- } \\
\text { bocza }\end{array}$ & $\begin{array}{c}\text { Zużycie } \\
\text { kapitału }\end{array}$ & $\begin{array}{c}\text { Ceny pro- } \\
\text { duktów } \\
\text { rolnych }\end{array}$ & $\begin{array}{c}\text { Wynagro- } \\
\text { dzenia }\end{array}$ & $\begin{array}{c}\text { Ceny } \\
\text { kapitału }\end{array}$ \\
\cline { 2 - 7 } & $\boldsymbol{Y}$ & $\boldsymbol{L}$ & $\boldsymbol{K}$ & $\boldsymbol{p}$ & $\boldsymbol{W}$ & $\boldsymbol{\boldsymbol { t }}$ \\
\hline Czechy & 144,31 & 50,72 & 195,95 & 77,20 & 266,66 & 88,16 \\
Słowacja & 124,10 & 28,53 & 109,46 & 63,31 & 341,39 & 76,07 \\
Litwa & 213,49 & 45,50 & 286,80 & 85,87 & 632,90 & 136,02 \\
Lotwa & 219,92 & 42,87 & 268,63 & 98,27 & 349,66 & 128,89 \\
Estonia & 232,45 & 36,83 & 695,64 & 92,23 & 501,66 & 132,36 \\
Polska & 166,21 & 66,28 & 139,47 & 91,79 & 316,79 & 138,90 \\
Węgry & 155,46 & 57,61 & 226,39 & 112,91 & 179,61 & 114,86 \\
\hline
\end{tabular}

Źródło: opracowanie własne na podstawie: [EUROSTAT, 2014].

Produkcję w każdym roku badanego okresu opisano za pomocą agregatów wielkości produkcji, wyrażonych w cenach stałych: praca została przedstawiona za pomoca liczby pełnozatrudnionych, a kapitał określono jako wielkość zużycia tego czynnika produkcji w cenach stałych. Druga grupę zmiennych stanowiły ceny, ukazane zwykle w formie indeksów. Stąd cena produktów rolnych uwzględniała owoce i warzywa. Natomiast jako odpowiednik cen kapitału przyjęto indeksy cen dóbr i usług zużywanych w danym roku w rolnictwie, a jako zmienną opisująca poziom wynagrodzeń wykorzystano iloraz wydatków związanych z wynagrodzeniami i liczby osób zatrudnianych i opłacanych w rolnictwie w danym roku. Wszystkie zmienne przeliczono w odniesieniu do wartości w roku 1997. Poziom zmian wielkości poszczególnych zmiennych obrazuje tabelaryczne zestawienie (tabela 1.) wartości indeksów dla ostatniego badanego roku. Dodatkowo na wykresie 1. zaprezentowano zmiany relatywnych cen i zmiany relatywnego zaangażowania w proces produkcji, zastosowane w analizie czynników.

W latach 1997-2013 największy przyrost produkcji rolniczej, sięgający około 120\%, stwierdzono na Litwie, Łotwie i w Estonii. Tymczasem ceny produktów rolnych spadały we wszystkich krajach z wyjątkiem Węgier, a najsilniejsze zmiany w tym zakresie odnotowano na Słowacji. W rolnictwie każdego z badanych państw ograniczano zaangażowanie siły roboczej przy jednoczesnym wzroście wynagrodzeń. Najsilniejszy spadek zat- 
rudnienia przekraczający $70 \%$ odnotowano na Słowacji, a najniższy, sięgający $35 \%$, w Polsce. Spadkom zatrudnienia towarzyszyły wzrosty wynagrodzeń na poziomie sięgającym od 80\% na Węgrzech do 530\% na Litwie. Z kolei zużycie kapitału w ciagu badanych 17 lat wzrosło we wszystkich krajach: niemal sześciokrotnie w Estonii i minimalnie na Słowacji. W obszarze cen kapitału zauważono spadki w Czechach i na Słowacji, a wzrosty w pozostałych krajach, jednak zmiany te okazały się dużo słabsze, niż te dotyczące wynagrodzeń.

RYSUNEK 1.

Zmiany relatywnych cen oraz relatywnego wykorzystania czynników wytwórczych w rolnictwie wybranych krajów Europy Środkowo-Wschodniej w roku $2013(1997=100)$

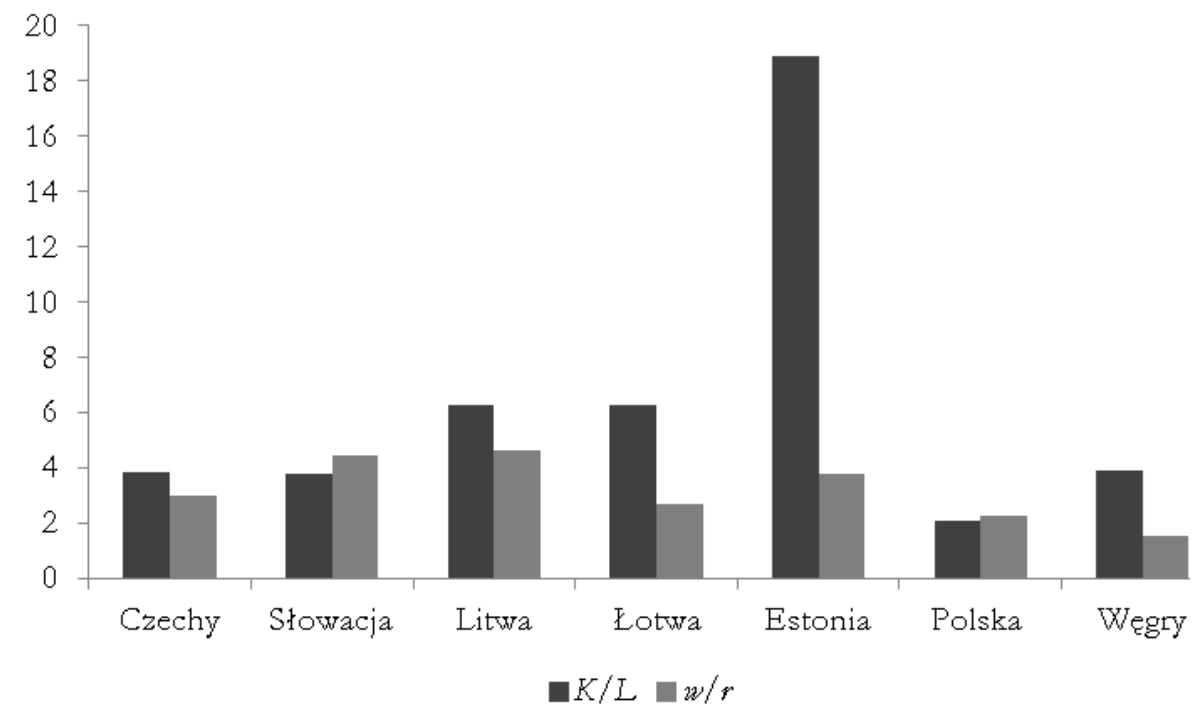

Źródło: opracowanie własne na podstawie: [EUROSTAT, 2013].

\section{Wyniki badań}

Przeprowadzona analiza polegała przede wszystkim na estymacji parametrów dynamicznej funkcji CES osobno dla rolnictwa każdego z analizowanych państw. Wykładniki funkcji postępu technicznego ustalono na poziomie $\gamma=3$. Poziom ten gwarantował wysoki stopień dopasowania modeli i istotność uzyskanych ocen estymacji. $\mathrm{Na}$ drugim etapie badania wyznaczono krańcowe stopy substytucji pomiędzy pracą a kapitałem i porównano je z odwróconymi stosunkami cen tych czynników.

Wartości ocen parametrów wyznaczonych na podstawie estymacji i współczynniki determinacji dla poszczególnych modeli zestawiono w tabeli 2. Pod każdą oceną w na- 
wiasie umieszczono jego odchylenie standardowe. Należy przypomnieć, że parametry $\beta_{1}$ oraz $\beta_{2}$ pełnią w tym modelu funkcję wyrazów wolnych (porównaj wzór (7)). Oszacowane funkcje okazały się dobrze dopasowane w przypadku każdego z siedmiu analizowanych państw. Pozostałe parametry okazały się istotne, z wyjątkiem $\beta_{\lambda} \mathrm{w}$ przypadku rolnictwa łotewskiego i słowackiego. Ze względu na strukturę szacowanego modelu nie można pominąć tego parametru.

TABELA 2.

Oceny parametrów regresyjnych oraz współczynniki determinacji oszacowane dla rolnictwa badanych krajów w latach 1997-2013

\begin{tabular}{|c|c|c|c|c|c|c|}
\hline & \multirow{2}{*}{$\begin{array}{c}\begin{array}{c}\text { Współczynnik } \\
\text { determinacji }\end{array} \\
\boldsymbol{R}^{2}\end{array}$} & \multicolumn{5}{|c|}{ Oceny parametrów regresyjnych } \\
\hline & & $\beta_{1}$ & $\beta_{2}$ & $\sigma$ & $\beta_{\delta}$ & $\beta_{\lambda}$ \\
\hline Czechy & 0,924 & $\begin{array}{l}0,102 \\
(0,067) \\
\end{array}$ & $\begin{array}{r}-0,338 \\
(0,077) \\
\end{array}$ & $\begin{array}{l}0,312 \\
(0,150)\end{array}$ & $\begin{array}{l}0,00013 \\
(0,00005) \\
\end{array}$ & $\begin{array}{r}-0,00006 \\
(0,00002) \\
\end{array}$ \\
\hline Słowacja & 0,965 & $\begin{array}{r}-0,004 \\
(0,055)\end{array}$ & $\begin{array}{l}0,039 \\
(0,061)\end{array}$ & $\begin{array}{l}0,492 \\
(0,094)\end{array}$ & $\begin{array}{l}0,00014 \\
(0,00004)\end{array}$ & $\begin{array}{r}0,00000 \\
(0,00002)\end{array}$ \\
\hline Litwa & 0,957 & $\begin{array}{l}0,041 \\
(0,098)\end{array}$ & $\begin{array}{r}-0,391 \\
(0,099)\end{array}$ & $\begin{array}{l}0,348 \\
(0,096)\end{array}$ & $\begin{array}{l}0,00019 \\
(0,00004)\end{array}$ & $\begin{array}{r}-0,00004 \\
(0,00003)\end{array}$ \\
\hline Łotwa & 0,962 & $\begin{array}{l}0,072 \\
(0,047)\end{array}$ & $\begin{array}{r}-0,366 \\
(0,064)\end{array}$ & $\begin{array}{l}0,525 \\
(0,114)\end{array}$ & $\begin{array}{l}0,00021 \\
(0,00004)\end{array}$ & $\begin{array}{r}-0,00001 \\
(0,00002)\end{array}$ \\
\hline Estonia & 0,946 & $\begin{array}{r}-0,133 \\
(0,149)\end{array}$ & $\begin{array}{r}-0,564 \\
(0,140)\end{array}$ & $\begin{array}{l}0,681 \\
(0,206)\end{array}$ & $\begin{array}{l}0,00021 \\
(0,00007)\end{array}$ & $\begin{array}{r}-0,00018 \\
(0,00004)\end{array}$ \\
\hline Polska & 0,938 & $\begin{array}{r}-0,028 \\
(0,079)\end{array}$ & $\begin{array}{r}-0,208 \\
(0,066)\end{array}$ & $\begin{array}{l}0,299 \\
(0,098)\end{array}$ & $\begin{array}{l}0,00015 \\
(0,00002)\end{array}$ & $\begin{array}{r}0,00008 \\
(0,00002)\end{array}$ \\
\hline Węgry & 0,926 & $\begin{array}{l}0,136 \\
(0,061)\end{array}$ & $\begin{array}{r}-0,521 \\
(0,073)\end{array}$ & $\begin{array}{l}0,467 \\
(0,141)\end{array}$ & $\begin{array}{l}0,00014 \\
(0,00003)\end{array}$ & $\begin{array}{r}-0,00004 \\
(0,00002)\end{array}$ \\
\hline
\end{tabular}

Źródło: opracowanie własne.

Spośród parametrów zamieszczonych w tabeli 2. interpretację ekonomiczną posiada parametr $\sigma$ (porównaj wzór (5)). Najwyższe elastyczności substytucji w rozumieniu Hicksa pomiędzy pracą a kapitałem wykazano w przypadku rolnictwa estońskiego: $1 \%$ wzrost relatywnych wynagrodzeń $(\boldsymbol{w} / \boldsymbol{r})$ skutkował w tych gospodarkach spadkiem o około $0,7 \%$ (w tabeli 2. jest to wartość 0,681$)$ relatywnego zatrudnienia $(\boldsymbol{K} / \boldsymbol{L})$. Elastyczność substytucji wyznaczona dla rolnictwa pozostałych analizowanych państw wynosiła około $0,3 \%$ w Polsce, w Czechach i na Litwie (w tabeli 2. wartości odpowiednio: 0,299; 0,312; 0,348) oraz 0,5\% dla Weegier, Słowacji i Łotwy (w tabeli 2. wartości odpowiednio: 0,467; 0,492; $0,525)$. Można zatem stwierdzić, że na relatywne zmiany cen stosunkowo najbardziej elastycznie reagowal rynek estoński.

Wyznaczone na podstawie wyników estymacji parametry funkcji CES zestawiono w tabeli 3. (porównaj wzory (8)). Ze względu na fakt, że dane zostały przedstawione w postaci indeksów, interpretacja parametrów efektywności $A$ oraz struktury $v$ zosta- 
nie pominięta. Jednak należy zwrócić uwagę, że mimo tej trudności, wyznaczone wartości spełniają stawiane przed nimi warunki: $0>v>1 ; A>0$.

Ocena podstawowych parametrów funkcji CES

TABELA 3.

\begin{tabular}{|c|c|c|c|c|c|c|}
\hline & \multirow[t]{2}{*}{$\begin{array}{c}\text { Parametr } \\
\text { efektywności }\end{array}$} & \multirow[t]{2}{*}{$\begin{array}{l}\text { Parametr } \\
\text { struktury }\end{array}$} & \multirow[t]{2}{*}{$\begin{array}{l}\text { Współczynnik } \\
\text { substytucji }\end{array}$} & \multicolumn{3}{|c|}{$\begin{array}{c}\text { Parametry postępu tech- } \\
\text { nicznego } \\
\text { w obszarze }\end{array}$} \\
\hline & & & & $\begin{array}{l}\text { siły ro- } \\
\text { boczej }\end{array}$ & kapitału & \\
\hline & $A$ & $\boldsymbol{V}$ & $\varrho$ & $\delta$ & $\lambda$ & $\delta-\lambda$ \\
\hline Czechy & 0,621 & 0,253 & 2,201 & 0,0002 & $-0,0001$ & 0,0003 \\
\hline Słowacja & 0,526 & 0,520 & 1,032 & 0,0003 & 0,0000 & 0,0003 \\
\hline Litwa & 0,503 & 0,246 & 1,871 & 0,0003 & $-0,0001$ & 0,0004 \\
\hline Lotwa & 0,345 & 0,332 & 0,905 & 0,0004 & 0,0000 & 0,0004 \\
\hline Estonia & 0,052 & 0,304 & 0,469 & 0,0006 & $-0,0006$ & 0,0012 \\
\hline Polska & 0,601 & 0,333 & 2,343 & 0,0002 & 0,0001 & 0,0001 \\
\hline Węgry & 0,378 & 0,247 & 1,140 & 0,0003 & $-0,0001$ & 0,0003 \\
\hline
\end{tabular}

Źródło: opracowanie własne.

Z ekonomicznego punktu widzenia interesujące są wartości różnic: $\delta$ - $\lambda$. W każdym przypadku przyjęły one wartości dodatnie, co oznacza, że w latach 1997-2013 w rolnictwie wybranych państw Europy Środkowo-Wschodniej postęp techniczny bardziej oddziaływał na siłę roboczą niż na kapitał, co w efekcie powodowało silniejsze ograniczenie zatrudnienia w procesie produkcji rolniczej. Zaprezentowany w artykule sposób estymacji nie rozstrzyga jednak o czynnikach wywołujących postęp techniczny. Jak wspomniano na wstępie, może on mieć pochodzenie endogeniczne lub egzogeniczne. W przypadku analizowanych państw kierunek zmian $\mathrm{w}$ strukturze zaangażowanych $\mathrm{w}$ procesie produkcji czynników jest zgodny ze zmianami odwróconego stosunku ich cen. W takiej sytuacji prawdziwa jest hipoteza Hicksa, mówiąca, że postęp techniczny jest kierowany w obszar czynnika relatywnie szybciej drożejącego. Wniosek ten jest zgodny z wartościami zmian liczby pełnozatrudnionych i zużyciem kapitału trwałego, przedstawionymi w tabeli 1. i na wykresie 1. Jednakże należy zwrócić uwagę, że postęp techniczny w przypadku rolnictwa krajów funkcjonujących w ramach Unii Europejskiej lub korzystających z funduszy przedakcesyjnych może mieć także źródło egzogeniczne: związane chociażby z systemem dopłat wspierających procesy restrukturyzacyjne.

W warunkach konkurencji doskonałej zmiany w produktywności krańcowej pracy są zbieżne ze zmianami w obszarze wynagrodzeń, a zmiany w obszarze produktywności kapitału sa zgodne ze zmianami w cenach kapitału. Na drugim etapie badań przeprowadzono zatem weryfikację tych założeń. Niemniej warto pamiętać, że w warunkach konkurencji doskonałej efekt zastapienia jednego czynnika produkcji innym nie może być mniejszy niż koszt związany z tą zmianą [Allen, 1961, s. 662]. Dlatego spełnienie hipotezy Hicksa należy wiązać $z$ tym, że niewielkie zmiany w relatywnych cenach powinny wywoływać silniejsze zmiany w krańcowej stopie substytucji. Mimo to ważne jest, 
aby kierunek tych zmian był zgodny. Zestawienie na wykresie 2. obu tych wartości wskazuje, że najsilniejsze efekty Hicksa odnotowano w przypadku gospodarki: czeskiej, litewskiej i polskiej. Wniosek ten potwierdziła analiza współczynników korelacji pomiędzy wspomnianymi wielkościami, zamieszczona w ostatniej kolumnie tabeli 4 .

Ze względu na przyjęte założenia najmniejszą wiarygodnością charakteryzuje się model dotyczący rolnictwa estońskiego. Współczynnik korelacji krańcowej stopy substytucji i odwróconego stosunku cen przyjął bardzo niskie wartości $(\mathrm{r}=-0,111)$. Porównując ten fakt $z$ wartościami przedstawionymi w tabeli 1 . i na wykresach: 1. i 2., można zauważyć, że w kraju tym w badanym okresie uzbrojenie stanowiska pracy wzrosło blisko dziewiętnastokrotnie, podczas gdy wynagrodzenia wyrażone w cenach kapitału wzrosły tylko 3,79 razy. Z kolei najlepiej spełnione założenie o gospodarce wolnorynkowej odnotowano w przypadku rolnictwa: polskiego, czeskiego i litewskiego. Biorac pod uwagę dane empiryczne zawarte w tabeli 1., można stwierdzić, że w krajach tych relatywne zmiany cen były zbliżone (co do kierunku) do relatywnych zmian wykorzystania czynników produkcji. Przedstawiono je na wykresie 2.

Co więcej, na podstawie analizy danych zestawionych na wykresie 2. i trzech ostatnich kolumn tabeli 4. można skonstatować, że w rolnictwie: czeskim, litewskim, estońskim i węgierskim zmiany krańcowej stopy substytucji były bardziej zbliżone przed akcesją niż po uzyskaniu przez te kraje pełnego członkostwa w Unii Europejskiej. Natomiast na Słowacji, Łotwie i w Polsce lepsze dopasowanie osiagnięto po przystąpieniu do Unii Europejskiej.

Bardziej szczegółową ocenę spełnienia założenia, że produkcja rolna była prowadzona w warunkach wolnej konkurencji, przeprowadzono dzięki analizie współczynników korelacji zmian cen i produktywności krańcowych osobno dla okresu przedakcesyjnego (1997-2004) oraz poakcesyjnego (2005-2013). Zestawiono ją w pierwszych kolumnach tabeli 4.

W obszarze pracy wykazano większą zgodność pomiędzy zmianami w obszarze wynagrodzeń a osiaganą przez rolników produktywnością niż w odniesieniu do analogicznych wielkości dotyczących kapitału. Świadczą o tym wyższe wartości współczynników korelacji zarówno w okresie przedakcesyjnym, jak poakcesyjnym. W przypadku rolnictwa: łotewskiego, węgierskiego i litewskiego siła tego związku spadła po uzyskaniu przez te państwa pełnego członkostwa w Unii Europejskiej. Tymczasem w rolnictwie estońskim wzrostowi wynagrodzeń towarzyszył, szczególnie po kryzysie 2008 roku, spadek efektywności.

Większe niedoskonałości w obszarze spełnienia warunku o konkurencyjności doskonałej odnotowano w obszarze kapitału trwałego. Poza tym, w większości państw w okresie przedakcesyjnym (z wyjątkiem Łotwy i Czech) wzrostowi cen tego czynnika towarzyszył wzrost zużycia tego czynnika i w efekcie spadek jego produktywności krańcowej. 
RYSUNEK 2.

Zmiany stosunku cen oraz krańcowej stopy substytucji w rolnictwie wybranych krajów Europy Środkowo-Wschodniej, w latach 1997-2013
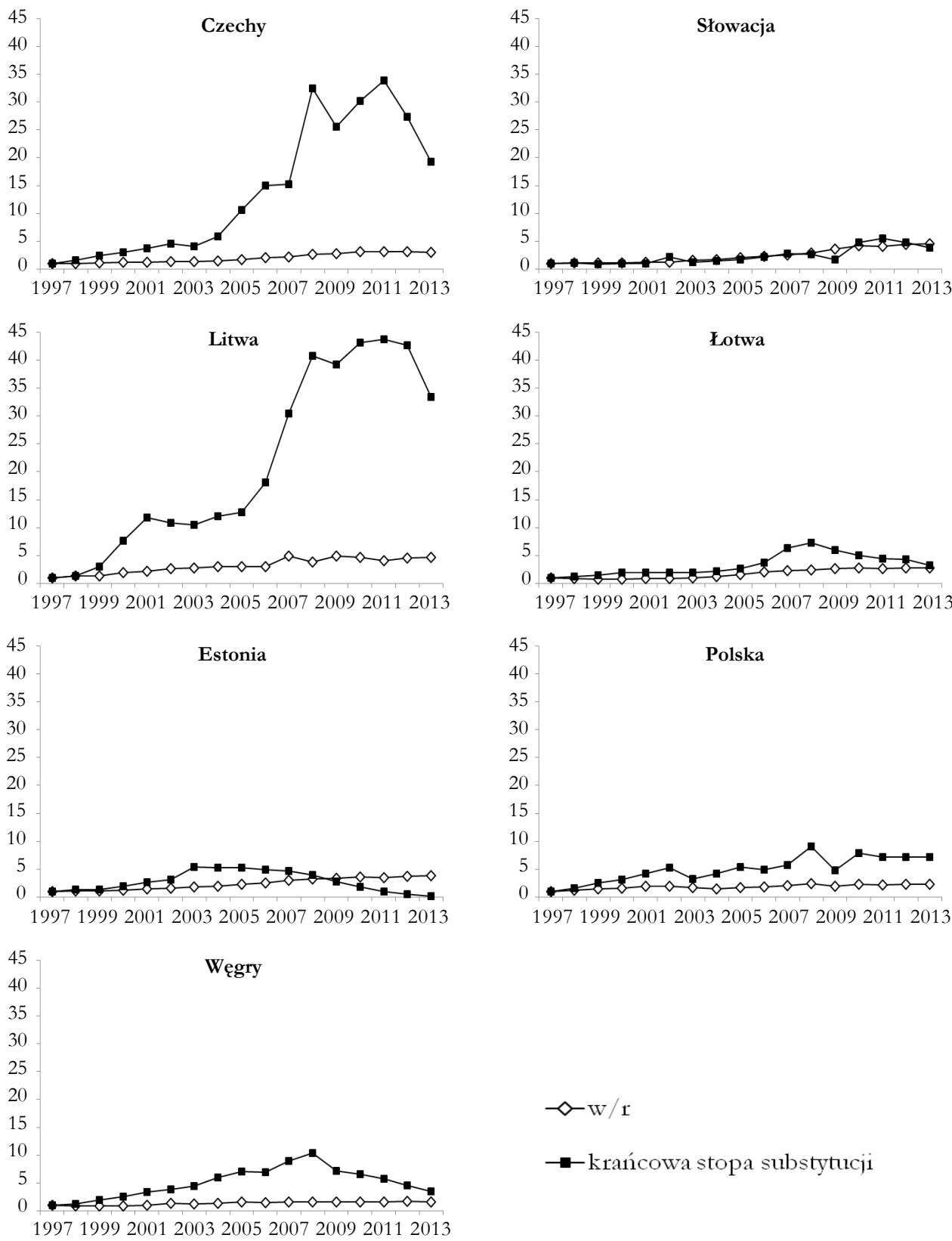

$\diamond-\mathrm{w} / \mathrm{r}$

$\rightarrow$-krańcowa stopa substytucji

Źródło: opracowanie własne. 
TABELA 4.

Korelacja pomiędzy cenami czynników wytwórczych i ich produktywnościami krańcowymi w latach 1997-2013

\begin{tabular}{|l|c|c|c|c|c|c|c|}
\hline & \multicolumn{2}{|c|}{$\begin{array}{c}\text { Wynagrodzenia } \\
\text { i produktywność } \\
\text { pracy }\end{array}$} & \multicolumn{2}{c|}{$\begin{array}{c}\text { Ceny kapitału } \\
\text { i produktywność } \\
\text { kapitału }\end{array}$} & \multicolumn{2}{c|}{$\begin{array}{c}\text { Stosunek cen oraz krańcowa } \\
\text { stopa substytucji }\end{array}$} \\
\cline { 2 - 8 } & $\mathbf{1 9 9 7 -}$ & $\mathbf{2 0 0 5 -}$ & $\mathbf{1 9 9 7 -}$ & $\mathbf{2 0 0 5 -}$ & $\mathbf{1 9 9 7 -}$ & $\mathbf{2 0 0 5 -}$ & $\mathbf{1 9 9 7 -}$ \\
& $\mathbf{- 2 0 0 4}$ & $\mathbf{- 2 0 1 3}$ & $\mathbf{- 2 0 0 4}$ & $\mathbf{- 2 0 1 3}$ & $\mathbf{- 2 0 0 4}$ & $\mathbf{- 2 0 1 3}$ & $\mathbf{- 2 0 1 3}$ \\
\hline Czechy & 0,625 & 0,830 & 0,554 & 0,690 & 0,983 & 0,818 & 0,956 \\
Słowacja & 0,754 & 0,760 & $-0,272$ & 0,754 & 0,247 & 0,774 & 0,882 \\
Litwa & 0,856 & 0,767 & $-0,587$ & 0,513 & 0,926 & 0,732 & 0,919 \\
Lotwa & 0,691 & 0,390 & 0,546 & 0,612 & 0,142 & 0,318 & 0,823 \\
Estonia & 0,902 & $-0,643$ & $-0,580$ & 0,717 & 0,967 & $-0,904$ & $-0,111$ \\
Polska & 0,687 & 0,828 & $-0,391$ & 0,628 & 0,879 & 0,916 & 0,949 \\
Wegry & 0,894 & 0,514 & $-0,757$ & 0,650 & 0,825 & $-0,106$ & 0,781 \\
\hline
\end{tabular}

Źródło: opracowanie własne.

\section{Podsumowanie}

Realizacja celów pracy polegała na estymacji funkcji CES przy założeniu, że produkcja rolnicza wybranych krajów Europy Środkowo-Wschodniej odbywała się w latach 1997-2014 w warunkach konkurencji doskonałej. Weryfikacja założeń tej estymacji stała się punktem wyjścia do odpowiedzi na pytanie, na ile rolnictwo unijne jest jeszcze liberalne.

Analiza danych empirycznych wykazała, że produkcja rolna we wszystkich badanych krajach wzrosła, przy spadku bądź niewielkim wzroście cen produktów rolnych. Jednocześnie w warunkach silnych wzrostów wynagrodzeń ograniczano zaangażowanie w procesie produkcji pracy. Następowało to dzięki wzrostowi zużycia wolno drożejącego kapitału. Można zatem mówić, że zmiany te były uwarunkowane przede wszystkim rynkowo. Przeprowadzone analizy wykazały także największą elastyczność substytucji czynników produkcji w obszarze rolnictwa słowackiego i estońskiego, a najsłabszą w rolnictwie polskim.

Z kolei analiza dotycząca postępu technicznego dowiodła, że działał on we wszystkich badanych krajach w kierunku ograniczenia siły roboczej. W niektórych przypadkach parametr związany z postępem technicznym, skierowanym w obszar kapitału, okazał się nieistotny, podczas gdy dane empiryczne wskazywały na silne oszczędzanie siły roboczej i dużą dynamikę przyrostu wartości kapitału. $\mathrm{Na}$ tej podstawie można więc stwierdzić, że postęp techniczny miał w tych krajach nie tylko źródła rynkowe, ale i egzogeniczne, które można wiązać z proinnowacyjnymi działaniami unijnymi, realizowanymi w ramach WPR.

Weryfikacja przyjętych założeń o równości krańcowej stopy substytucji i relatywnego stosunku cen pokazała, że najmniejszą wiarygodnością charakteryzuje się model dotyczący rolnictwa estońskiego, a najlepiej spełnione to założenie odnotowano w przypad- 
ku rolnictwa: polskiego, czeskiego i litewskiego. Ponadto największą zgodność, co do spełnienia warunku o prowadzeniu produkcji rolnej bez naruszania zasad wolnokonkurencyjnych, stwierdzono w obszarze siły roboczej. W związku z tym działania podejmowane $\mathrm{w}$ ramach WPR, ingerujące $\mathrm{w}$ ilość zatrudnionych $\mathrm{w}$ rolnictwie, wydają się $\mathrm{w}$ mniejszym stopniu zakłócać wolny rynek produktów żywnościowych niż te, które pośrednio wpływają na ilość kapitału zaangażowanego w procesie produkcji rolniczej.

\section{Literatura}

Allen R. D. G. 1961 Ekonomia matematyczna, Wydawnictwo Naukowe PWN, Warszawa. Arrow K. J., Chenery H. B., Minhas B. S., Solow R. M. 1961 Capital-Labor Substitution and Economic Efficiency, „Review of Economics and Statistics”, no. 43.

Begg D., Fisher S., Dornbusch R. 1995 Ekonomia t. 1, PWE, Warszawa.

Błażejczyk-Majka L., Kala R. 2005 Estymacja elastyczności substytucji na praylkładzie rolnictwa francuskiego w latach 1980-2000, „,Roczniki Nauk Rolniczych, Seria G”, nr 92.

Błażejczyk-Majka L., Kala R. 2009 Ekonometryczna weryfikacja podstaw teorii indukowanego rozpoju w sektorze rolnictwa wybranych krajón UE, Wydawnictwo Uniwersytetu Przyrodniczego w Poznaniu, Poznań.

Czyżewski A., Henisz-Matuszczak A. 2004 Rolnictwo Unii Europejskiej i Polski. Studium porónnawcze struktur nytwórcsych i regulatorów rynków rohyych, Wydawnictwo Akademii Ekonomicznej w Poznaniu, Poznań.

Duczkowska-Małysz K. 1998 Rolnictwo - wieśs - państwo. Wokót interwenciï państwa w sfere wsi i rolnictwa, Wydawnictwo Naukowe PWN, Warszawa.

EUROSTAT, dokument elektroniczny, tryb dostępu: [http://epp.eurostat.cec.eu.int/, data wejścia: 2.05.2014].

Felbur S. 1997 Tendencie postępu technicznego w Polsce (aspelet innowacyjności i efektywności). Raporty, Instytut Rozwoju i Studiów Strategicznych, Warszawa.

Hicks J. R. 1932 The Theory of Wages, Macmillan, London.

Intriligator M. D. 1957 Embodied Technical Change and Productivity in the United States 19291958, „Review of Economics and Statistics”, no. 39.

Kawagoe T., Otsuka K., Hayami Y. 1986 Induced Bias of Technical Change in Agriculture: The United States and Japan, 1880-1980, ,Journal of Political Economy”, no. 94.

Klump R., Preissler H. 2000 CES Production Function and Economic Growth, „Scandinavian Journal of Economics", no. 102.

Marciniak S. 2000 Innowacje i rozwój gospodarcsy, Kolegium Nauk Społecznych i Administracji Politechniki Warszawskiej, Warszawa.

Pawłowski Z. 1976 Ekonometryczna analiza procesu produkcyjnego, Wydawnictwo Naukowe PWN, Warszawa.

Poczta W. 2001 Wspólna polityka rolna Unii Europejskiej, [w:] Gospodarstwa rolne w Unii Europejskiej. Koraysści i koszty, M. Markiewicz (red.), Fundacja na Rzecz Rozwoju Polskiego Rolnictwa, Warszawa.

Poczta W. 2010 Præemiany w rolnictwie, [w:] Polska wieś 2010. Raport o stanie wsi, J. Wilkin, I. Nużyńska (red.), Wydawnictwo Naukowe Scholar, Warszawa. 
Solow R. M. 1962 Technical Change, Capital Formation and Economic Growth, „The American Economic Review", no. 52.

Walkowski M. 1998 Wspótczesne tendencje w rozwoju europejskich procesów integracyjnych, Wydawnictwo Naukowe UAM, Poznań.

Welfe W., Welfe A. 2004 Ekonometria stosowana, Wydawnictwo Naukowe PWN, Warszawa.

Wilkin J. 1986 Wspótczesna kiwestia agrarna, Wydawnictwo Naukowe PWN, Warszawa.

Woś A. 1987 Rozwój i postęp w rolnictwie polskim, PWRiL, Warszawa.

Woś A. 1998 Wrost gospodarczyy i strategie polskiego rolnictwa. Eseje 2, IERiGŻ, Warszawa.

Yeung P., Roe T. 1971 Induced Innovation: A CES - Type Meta - Production Function, Staff Paper P71-27, Department of Agricultural and Applied Economics, University of Minnesota, Minnesota.

Zellner A. 1962 An Efficient Method of estimating Seemingly Unrelated Regressions and Tests for Aggregation Bias, ,Journal of American Statistics Association”, no. 57.

Zrozumieć polityke Unï Europejskiej - Rolnictwo 2013, Komisja Europejska, Bruksela, dokument elektroniczny, tryb dostępu: [http://europa.eu/pol/agr/index_pl.htm, data wejścia: 9. 06. 2014].

Żółtowska E. 1997 Funkccje produkciji. Teoria, estymacja, zastosowania, Wydawnictwo Uniwersytetu Łódzkiego, Łódź. 